Bolm Inst. oceanogr., S Paulo, 32(1):77-81, 1983

\title{
INFLUENCE OF MARINE AND CONTINENTAL PROCESSES ON THE DYNAMICS OF A SAND-RIDGE AT THE MOUTH OF THE MAÇ.AGUAÇU RIVER (CARAGUATABUBA - SP): PRELIMINARY CONDITIONS
}

May Christine MODENESI ${ }^{1}$; Moysēs Gonsalez TESSLER ${ }^{2}$; 01 ga CRUZ $^{1}$ \& Armando Marcio COIMBRA ${ }^{3}$

1 Instituto de Geografia da Universidade de São Paulo

2 Instituto Oceanográfico da Universidade de São Paulo

3 Instituto de Geociências da Universidade de São Paulo

\section{Synopsis}

This paper deals with the sedimentation and erosion dynamics of a sand-midge on the Macaguacu River mouth on the São Paulo coastal plain, north of Caraguatatuba Bay. Sedimentological, climatic and hydrodynamic data were analysed from an integrative point of view, considering relationships between continental and marine antagonic forces. Even if incomplete these preliminary observation show that erosion only occurs when more intense rains and higher tidal cycles coincide and that even the intense occurrence of one of these phenomena is not enough to trigger the destructive processes.

Descriptors: Maçaguaçu river, fluvial morphology, coastal erosion, sediments, tides, rainfall, winds. Descritores: Rio Maçaguaçu, morfologia fluvial, erosão costeira, sedimentos, marēs, chuva, vento.

\section{Introduction}

The coast of the State of São Paulo (Fig. 1) shows two distinct segments north and south of the Santos-Bertioga region - different in their morphological and sedimentological characteristics. Between these two coastal segments, a progressive transition exists, which seems to indicate a differential continental flexure mechanism (Suguio \& Martin, 1978).

From Santos southward, a straight shoreline develops. Marine and fluvio-lagoonal sediments form a large and extensive coastal plain. In the northern segment, where Precambrian basement lies near the coast, the shoreline is irregular (indented) and consists of a succession of rocky headlands and small bay-head beaches (pocket beaches); the Caraguatatuba coastal plain is the only significant marine depositional area.

Maçaguaçu Beach is an exposed steep beach in front of a small coastal plain situated immediately north of Caraguatatuba Bay. It faces south toward the Island and Channel of São Sebastião. Maçaguaçu plain is of Holocenic age Publ. n. 585 do Inst. oceanogr. da Usp.

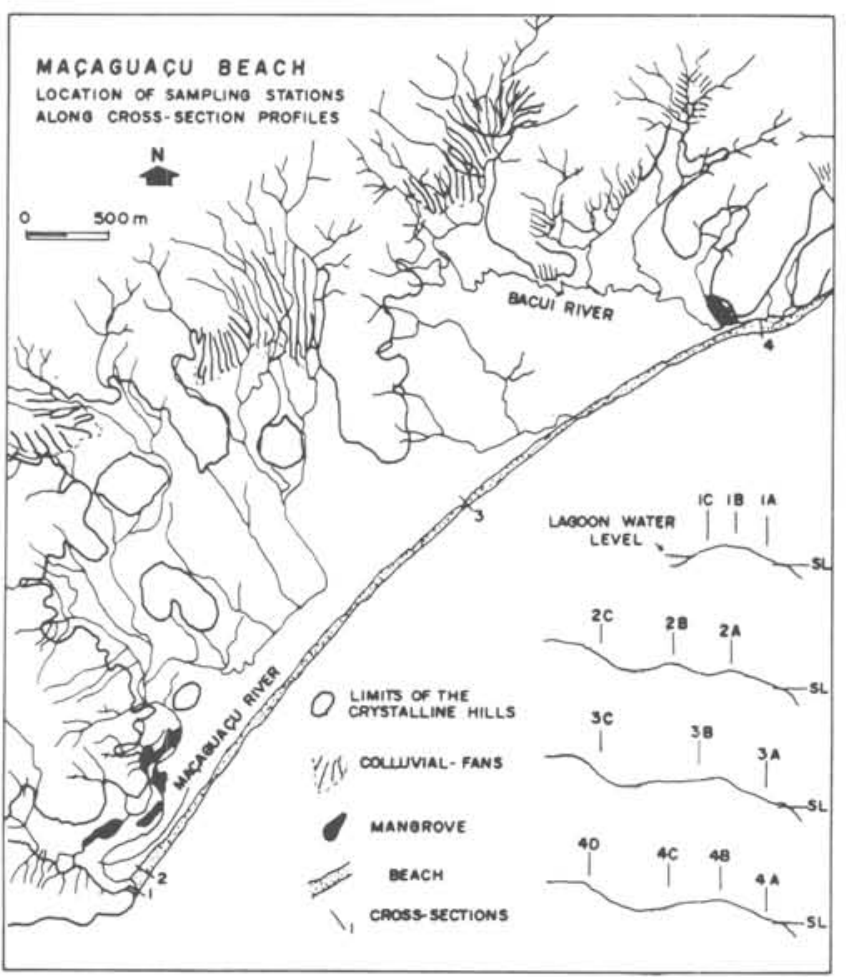

Fig. 1. Location of sampling stations along cross-section profiles in Maçaguaçu Beach. 
(Suguio \& Martin, op. cit.) and consists of sandy marine and sandy-clayey fluviolagoonal sediments partially covered by colluvial deposits. Mangrove is restricted to small areas along the lower course of rivers.

The coastal plain and crystalline hills are drained by the Maçaguaçu and Bacuí rivers and their tributaries. A sand-ridge closes the mouth of the Maçaguaçu River, forming a lagoon. Alternate constructive and destructive phases, in relatively short periods of time, characterize the dynamics of this ridge.

Preliminary analyses (field observations and aerophotointerpretation) demonstrated the interaction of antagonistic marine and continental processes, the latter apparently linked to intense pluvial events associated with the passage of cold polar fronts over the region. Similar associations have been suggested by Cruz et al. (in press) to explain the sedimentation dynamics of Caraguatatuba Bay.

These facts have determined the integrative methodological approach and the choice of parameters analysed. Morphological, sedimentological, and climatic (rainfall and winds) analyses were made and tide data analysed according to this view. There is a lack of measurements on longshore currents.

Sand-ridge destruction took place in the period between two excursions to the area (December 28, 1981 and January 8,1982 ) which restricted the period of analyses to December 1, 1981, to January $15,1982)$.

\section{Beach sediments}

The sands of Maçaguaçu Beach mostly consist of coarse to very coarse grains (Wentworth scale) which show medium to poor sorting (Folk \& Ward, 1957). A virtually symmetric distribution prevails. Kurtosis values define meso to platicurtic curves (Table 1).

In order to better characterize surface sediments, four sections were made normal to the coast between low tide level and the berm. Samples were taken according to variations in foreshore morphology (Fig. 1).

Section 1 was made on the sand-ridge, samples were collected at the top of it and on both the seaward and landward sides. Despite the similar grain-size ranges observed along the section (very coarse sand to granule modal values) the granule fraction increases on the landward side of the ridge (Sample 1C).

Table 1. Relative frequency values of Folk \& Ward (1957) parameters

\begin{tabular}{|c|c|c|}
\hline Medium diameter & $F R$ & FR. \& \\
\hline$-1.00-0.00$ & 3 & 21.43 \\
\hline $0.00-1.00$ & 8 & 57.14 \\
\hline $1.00-2.00$ & 3 & 21.43 \\
\hline Sorting & $F R$ & $F R$. \& \\
\hline $0.00-0.35 *($ Very well sorted $)$ & 1 & 7.14 \\
\hline $0.35-0.50 *($ Well sorted $)$ & 1 & 7.14 \\
\hline $0.50-1.00 *$ (Moderately sorted) & 11 & 78.57 \\
\hline $1.00-2.00 *($ Poorly sorted $)$ & 1 & 7.14 \\
\hline Skewness & FR & FR. \% \\
\hline$-1.00--0.30 *$ (Very negative skewed) & 1 & 7.14 \\
\hline$-0.30--0.10 *($ Negative skewed $)$ & 2 & 14.29 \\
\hline$-0.30-0.10 *($ Nearly symmetrical $)$ & 10 & 71.43 \\
\hline $0.10-0.30 *$ (Positive skewed) & 1 & 7.14 \\
\hline Kurtosis & $F R$ & FR. $\%$ \\
\hline $0.67-0.90 *($ Platykurtic) & 1 & 7.14 \\
\hline $0.90-1.11 *$ (Mesokurtic) & 7 & 50.00 \\
\hline $1.11-1.50 *$ (Leptokurtic) & 3 & 21.43 \\
\hline $1.50-3.00 *$ (Very leptokurtic) & 3 & 21.43 \\
\hline
\end{tabular}

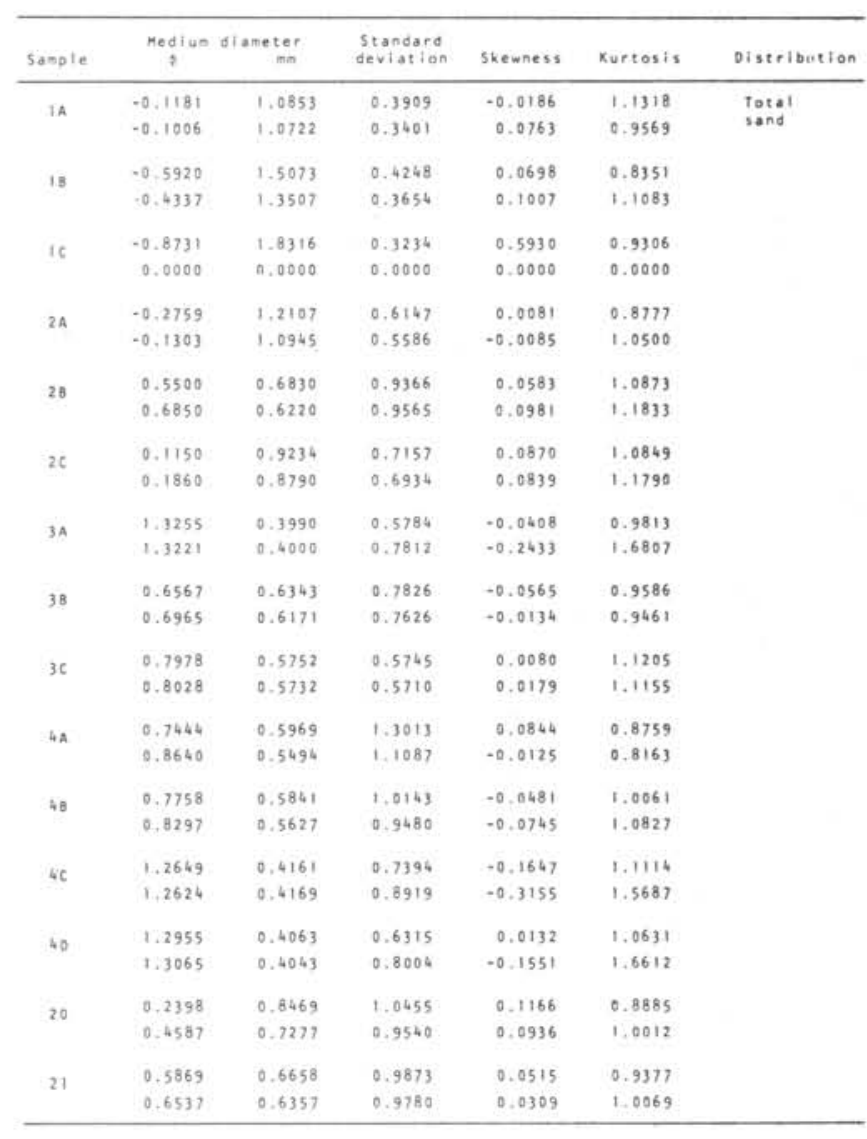


Section 2 samples show medium diameter values (Table 1) in the coarse to medium sand interval, with progressively diminishing values landward.

Standard deviation values for both sections ( 1 and 2 ) define medium sorting, except sample 1C which shows very good sorting.

The concentration of coarse sand and granules observed in sections 1 and 2 indicates a high-energy environment for the southern part of Maçaguaçu Beach.

Section 3 samples still present coarse grains with variations of medium diameter in the opposite direction; medium diameter values increase towards the interior, from medium (3/A) to coarse sand $(3 \mathrm{C})$. Sorting is medium.

Section 4 shows similar medium diameter values. The slight increase in the fine-sand fraction is reflected by a greater number of textural classes. Standard deviation values define medium to poor sorting grades.

Skewness values of samples from sections 1,2 and 3 show a tendency towards symmetrical distributions; a distribution pattern cannot be distinguished in section 4 samples.

Kurtosis shows no relation to sample distribution.

On the southern part of the beach, surface sediments are covered by some pebbles and by considerable amounts of whole, well-preserved shells. However, the amount of calcium carbonate incorporated into sediments is smal1 (2 to $4 \%$ ) when the entire beach is considered.

As the above mentioned data show, a decrease in the energy level of transportation occurs from south to north along the beach.

\section{Climatic conditions}

On the northern par of the State of São Paulo coastal plain, summer months are characterized by frequent, intense rainfall.

Precipitation and wind data at the time of this analysis - December 1, 1981 to January 15, 1982 - are shown in Figure 2 (Meteorological Station of the Oceanographic Institute - USP Enseada do Flamengo-Ubatuba).

Rainfa11 data for January 2, 3, 4 and 5 refer to minimum values, due to registration failure.

As Figure 2 shows, two important pluvial events occurred - from December 6 to 9, 1981 and from January 1 to 5,1982 - with total precipitation amounts of 150 and $230 \mathrm{~mm}$ respectively.

Southeastern winds prevail throughout the year but, as Monteiro (1963) and Conti (1975) point out, the permanence of this pattern seems to be linked to the passage of Atlantic Polar Fronts.

The pluvial events mentionned above differ in genesis. In the former, south and southwesterly winds prevailed; precipitation resulted from the penetration of maritime air masses in a post-frontal system. In the latter, southeasterly winds were constant and rainfall had a typical frontal genesis.

Wind intensity varies from weak to moderate and is practically the same during all seasons (Conti, op.cit.).

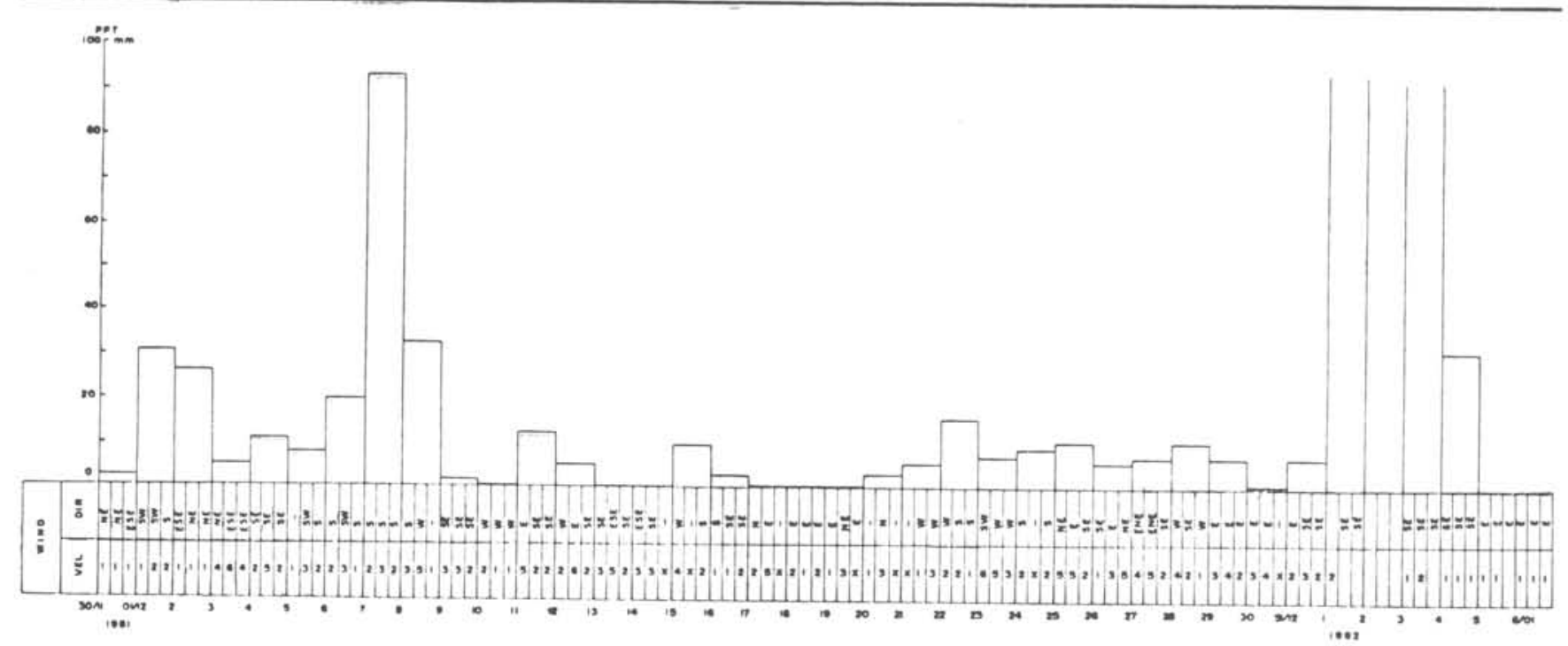

Fig. 2. Daily data on precipitation and wind direction and velocity. 


\section{Tides}

Tidal data were collected at the Ubatuba Base of the Oceanographic Institute. The given values represent relative levels of the tide related to the zero level of the tide gauge, hence without reference to tide base level (reduction leve1). No correction was made, since only relative variations are important.

A preliminary analysis shows tidal amplitude variations of approximately $90 \mathrm{~cm}$, with mean values for high tide around $140 \mathrm{~cm}$ and for low tide around $50 \mathrm{~cm}$ (Fig. 3).

Both on December 2-5, 1981, and January 2-3-4, 1982, tidal amplitude diminished considerably to values around $50 \mathrm{~cm}$, because of higher low-tide levels (approximately $100 \mathrm{~cm}$ ).

Although these values represent low tide levels, they are much higher than the general mean low tide levels. This fact resulted in long periods ( 3 days) of higher tide values.

\section{Final remarks}

Maçaguaçu beach comprises a high-energy environment. The energy level of transportation diminishes from south to north along the beach. As an accumulation feature, the sand-ridge at the mouth of the Maçaguaçu River clearly reflects these characteristics.
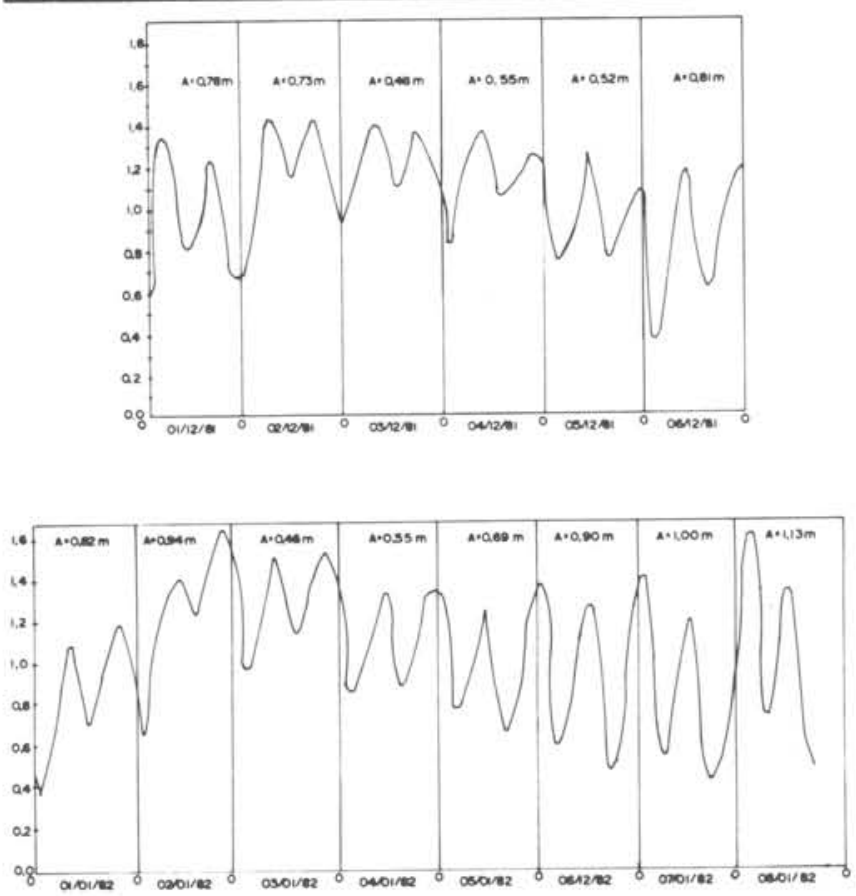

Fig. 3. Daily values of tidal amplitudes (Dec 81/Jan 82).
In the period delt with, two important pluvial events were observed together with higher tidal cycles. From December 6 to 9,1981 , post-frontal rains occurred when the tidal cycle was already at its usual levels. During the second event from January 1 to 5, 1982 - typical frontal rains and higher tide values coincided. Destructive processes took place only during the latter event.

High permeability of the coarse sands of the ridze and the difference between lagoonal c.nd tidal levels allow freshwater to flow seaward through the sediments without destroying the sandridge. Thus, even during periods of intense rainfall when the river's discharge increases, the lagoon does not stand much above its normal level.

When higher lagoonal water leve1a coincide with higher tidal cycles, the difference in heigth batween the two levels decreases. The position of the salt-water wedge, which according to the Ghyben-Herzberg relation (Todd, 1959) exists at the intersection of an aquifer with the ocean, is thus altered. Elevation of the fresh water-salt water interface occurs, raising flow lines to the top of the sand-ridge. This rise seems to be accompanied by a decrease in volume rather than by the total interruption of seaward flow.

Saturation with water destroys the apparent cohesion of sands (Terzaghi \& Peck, 1948) favoring its mobilization. The return of tidal levels to normal values, while lagoonal waters remain at maximum height, results in the rapid destruction of the ridge. Water saturated sands do not resist the pressure of lagoonal waters.

This would be the mechanism explaining the destruction of the sandridge but probably not the only one. Destructive action of storm waves during frontal passages should also be considered.

Observation of this feature during approximately one year shows that erosion only occurs when more intense rains and higher tidal cycles coincide and even the intense occurrence of one of these phenomena (Event 1) is not enough to trigger the destructive processes. Marine and continental processes act together, the latter clearly connected with the passage of cold fronts over the region. 


\section{Resumo}

A dinâmica de sedimentação e erosão do "spit-bar" do rio Maçaguaçu (Caraguatatuba, São Paulo) foi preliminarmente avaliada através da integração de estudos climāticos, hidrodinâmicos e sedimentológicos, considerando-se as inter-relaçoes das forças antagônicas entre os processos continental e marinho. A feição construtiva do "spit-bar" parece estar conectada com a dinâmica dos processos marinhos. Suas caracteristicas erosionais parecem ser o resultado dos processos fluviais, intimamente relacionados aos períodos de intensa pluviosidade nas escarpas da Serra do Mar, quando da passagem de frentes atmosféricas.

\section{Acknowledgements}

We wish to thank Dr. Thomas Fairchild for revision of the English text.

\section{References}

CONTI, J. B. 1975. Circulação secundāria e efeito orogrāfico na gênese de chuvas na região lesnordeste paulista. Sér. Teses Monogr., Inst. Geogr. Univ. S Paulo, (18):1-82.
SUGUIO, K. \& MARTIN, L. 1978.

Quaternary marine formations of the State of São Paulo and southern-Rio de Janeiro. Intern. Symp. Coastal Evolut. Quartenary, São Paulo, $55 \mathrm{p}$.

TERZAGHI: K. \& PECK, R. B. 1948. Soil mechanics in engineering practice. Ed. New York, Wiley, 566p.

TODD, D. K. 1959. Ground water hydrology. Wiley Intern. Ed., John and Sons Inc., New York, Viley, 366 p.

CRUZ, 0.; SUGUIO, K. \& EICHLER, B. Influências natural e antrópica na sedimentação acelerada de cordões arenosos atuais na Enseada de Caraguatatuba (In press).

FOLK, R. L. \& WARD, W. C. 1957. Brazos River bar: a study in the significance of grain size parameters. J. Sedim. Petrol., 27:3-27.

MONTEIRO, C. A. F. 1963. O clima da região sul. In: Geografia Regional do Brasil - Grande Região Sul. V. IV. Rio de Janeiro, IBGE, v.1. 